\title{
IgG4 Related Disease Imitating Cancer, Autoimmune and Infectious Diseases: A Case Report with Lung Involvement
}

\author{
Neoplastik, Otoimmün ve Enfeksiyöz Hastalıkları Taklit Edebilen IgG4 İlişkili \\ Hastalık: Akciğer Tutulumlu bir Olgu Sunumu
}

Onur Derdiyok', Nagehan Ozdemir Barisik², Sevinc Citak' , Cansel Atinkaya ${ }^{1}$, Irfan Yalçınkaya

\begin{abstract}
Plasma cell granuloma (PCG) is a rare benign tumor that is difficult to distinguish from malignancy. The terminology associated with PCG is inconsistent, with tumors referred to in literature also as inflammatory pseudotumor, fibrous histiocytoma or fibroxanthoma. Diagnosis: clinical features, serum lgG4 level, radiology and histopathological findings should be evalvated together. We present a case here that is very rare and newly described in literature in which a male patient presented to our clinic with a complaint of hemoptysis, resection due to a lesion on the lung who was subsequently diagnosed with $\lg G 4$-related disease.
\end{abstract}

Key words: IgG4, hemoptysis, fibrous histiocytoma.

\section{Özet}

Plazma hücresi granülomu (PCG), maligniteden ayırt edilmesi güç olan nadir görülen, iyi huylu bir tümördür. PCG ile ilişkili terminoloji ve literatürde tutarsızlık vardır ve bu tümörlere ayrıca enflamatuar psödotümör, fibröz histiyositoma veya fibroksantoma da denir. Tanı, klinik özellikler, serum lgG4 düzeyi, radyoloji ve histopatolojik bulguların birlikte değerlendirilmesi ile konmaktadır. Çok nadir görülen ve literatürde yeni tanımlanmış, kliniğimize hemoptizi şikayeti ile başvuran ve akciğerdeki bir lezyon nedeniyle rezeksiyon sonrası lgG4 ile ilişkili hastalık tanısı konulan bu olgumuzu sunduk.

Anahtar Sözcükler: lgG4, hemoptizi, fibröz histiyositoma.
'Department of Thoracic Surgery, University of Heath Sciences Süreyyapaşa Chest Diseases and Thoracic Surgery Training and Research Hospital, İstanbul, Turkey

${ }^{2}$ Department of Pathology, İstanbul Kartal Dr. Lütfï Kırdar Training and Research Hospital, İstanbul, Turkey
' Sağlık Bilimleri Üniversitesi Süreyyapaşa Göğüs Hastalıkları ve Göğüs Cerrahisi Eğitim ve Araştıma Hastanesi Gögüs Cerrahisi Klinigi, İstanbul

2istanbul Kartal Dr. Lüffi Kırdar Eğitïm ve Araş̧ırma Hastanesí, Patoloji Kliniği, İstanbul

Submitted (Başvuru tarihi): 04.09.2019 Accepted (Kabul tarihi): 07.11.2019

Correspondence (iletişim): Onur Derdiyok, Department of Thoracic Surgery, University of Heath Sciences Süreyyapaşa Chest Diseases and Thoracic Surgery Training and Research Hospital, İstanbul, Turkey

e-mail: derdiyokonur@gmail.com 
Immunoglobulin (Ig) G4-related disease (lgG4-RD) was first termed in pancreas and as an autoimmune pancreatitis (1). $\lg G 4-R D$ is a fibroinflammatory condition involving tumor growth with multiple lymphocytic leakage agents, including lgG4-positive plasma cells that may contain many regions (2). PCG or inflammatory pseudotumor is a rare lesion that can occur in almost every organ, including the lung, and that is predominantly intraparenchymal. Cardiac and pulmonary involvement, however, is rare (1) PCG abundantly and uniformly infiltrates pulmonary connective tissue, including lgG4 plasma cells, bronchovascular bundles, alveolar interstitium, interlobular septa and pleura. Pleural lesions manifest as a diffuse pleural thickening, accompanied by diffuse sclerosing inflammation and chronic lymphoplasmositic infiltration, with or without fibrosis. IgG4-RLD lesions mostly develop in peribronchial or perivascular connective tissues, the interlobular septa and the pleura. This distribution is essentially a map of the intrapulmonary lymphatic drainage system, and may be an important step in understanding the pathogenesis. PCG can be interpreted both clinically and radiologically as malignant. Imaging methods such as thorax computed tomography and magnetic resonance imaging are necessary to identify the location and metastasis. It is difficult to distinguish PCG from malignancy and fine needle aspiration, or from histologically frozen sections (2). A complete resection of PCG is necessary to reduce the risk of recurrence. A PCG is usually associated with pathological lgG4 levels, and a high serum lgG4 concentration may help differentiate between PCG and other tumors (3). The presence of a circulating plasmablast may be more sensitive as a marker for elevated $\lg G 4$ levels when $\lg G 4-R D$ is diagnosed, but this has not been investigated in our patient (4-6). In this study, we present a case of PCG.

\section{CASE}

A 28-year-old male patient was admitted to our clinic with hemoptysis. The physical examination and medical history were unremarkable. Laboratory parameters were normal. A posterior-anterior chest $X$-ray showed a minimal increase in density in the right lung middle lobe (Figure 1). A thorax computed tomography (CT) and positron emission tomography (PET-CT) were performed, and a solid mass extending to the pleura in the middle lobe of the right lung measuring $4.5 \mathrm{~cm}$ (SUVmax 2.8) was detected (Figure 2). A fiberoptic bronchoscopic examination (FOB) revealed a hemorrhagic appearance in the right upper lobe and middle lobe, although no endobronchial lesion was observed. No signs of malignancy were detected in the bronchial lavage material, aspiration or brush samples. No acidoresistant bacilli (ARB) were observed. A transthoracic fine needle aspiration was performed, but no diagnosis was made. Agglutinin tests for cyst hydatid were negative. Accordingly, we opted for surgery due to the continuation of hemoptysis attacks despite medical treatment. A mass associated with right middle lobe and upper lobe was detected after an exploratory thoracotomy. No frozen, benign / malignant distinction was made. A bilobectomy was performed due to hemoptysis complaints, malignancy suspicion and radical surgery. Histopathological examination: In addition to stromal hyalinization and fibrosisa widespread proliferation of plasma cells and occasional lymphoid aggregates were identified. Immunohistochemically, the plasma cells showed positive immunoreactivity with kappa and lambda. Intense $\lg G$ and $\lg G 4$ positivity was found in the plasma-labeled plasma cells (Figure 3). The present findings were interpreted as $\lg G 4$-related disease in the lung. No problems emerged in the following 8-month period.

\section{DISCUSSION}

lgG4-RD includes increased serum lgG4 concentrations and pathological findings of lymphoplasmic infiltration of lgG4-positive plasma cells with storiform fibrosis, as well as obliterative phlebitis in various organs (7). Diseases associated with lgG4 may involve many organs and may exist as autoimmune pancreatitis, Mikulicz's disease, Riedel's thyroiditis, retroperitoneal fibrosis and multifocal fibrosclerosis. Although lgG4 plays an important role in the pathogenesis of the disease, the mechanisms of elevation of $\lg G 4$ are not yet understood. T cells are thought to be associated with pathogenesis, having been found in many CD4-T cell inflammation sites in lgG4-related diseases. $\lg G 4-R D$ of the lung is relatively rare, and may be confined to the lung or may develop simultaneously in other organs, or metachronously (8).

The clinical and imaging findings of IgG4-RD are highly variable. While lung parenchymal involvement (mass-like lesion or interstitial lung disease) and mediastinal lymphadenopathy are typical, airway and pleural involvement are rare (9). In fact, several cases of IgG4-RD have been reported in the lung parenchymal interstitium, with or without disease, and in the bilateral pleura (10). 


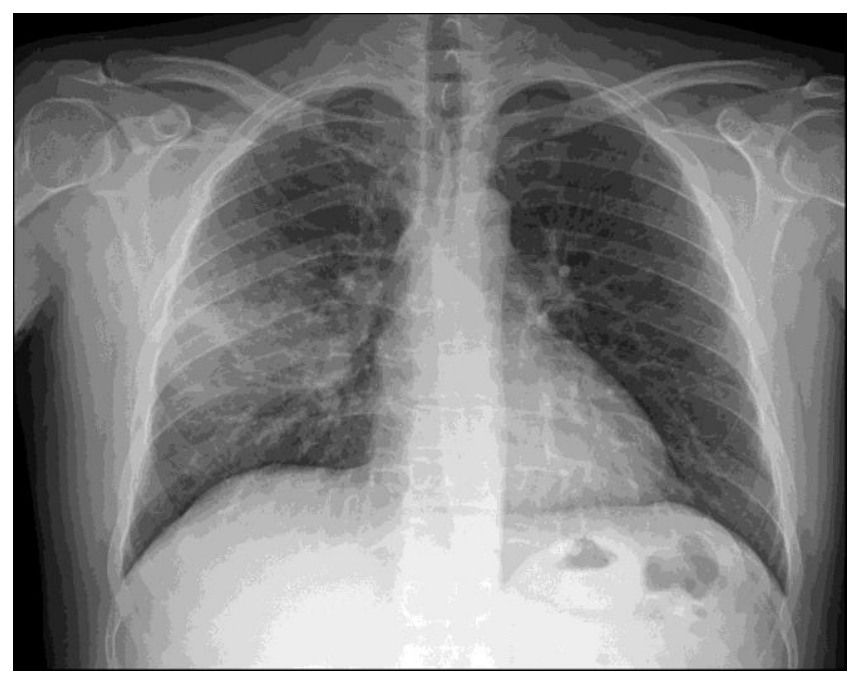

Figure 1: Minimal density increase in the right lung middle zone on a posterior-anterior chest X-ray

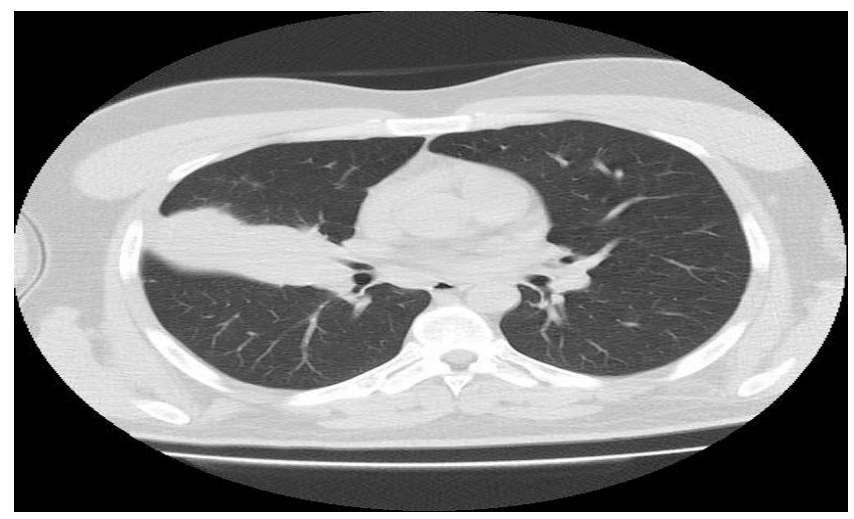

Figure 2: Thorax computed tomography showing a $4.5 \mathrm{~cm}$ solid mass in right lung middle lobe

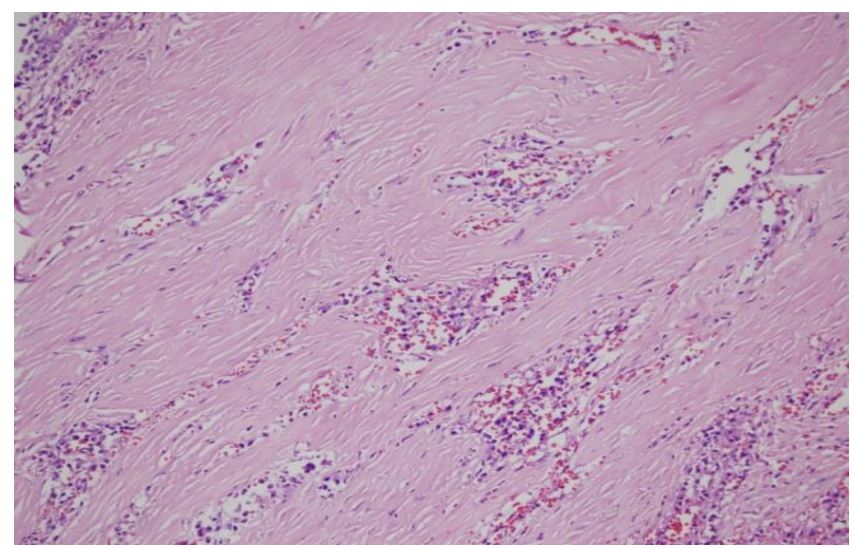

Figure 3: Histopathological image of plasma cell islands found in a hyalinized stroma (H\&E X 100)

Numerous eosinophil can also be seen in the lung and other related regions. In October 2011, an international symposium on IgG4-RD was held in Boston, MA in which two reports were prepared on the naming of this condition, its organ system manifestations and the spectrum (11). In these reports, lung involvement was determined as $\lg G 4-R D$, which is the term adopted in this review.
lgG4-RLD may explain a significant subgroup of fibroinflammatory disorders that are of unknown origin in thoracic medicine, such as inflammatory pseudotumor of the lung (known also as IPT, and as plasma cell granulo$\mathrm{ma})$, non-specific interstitial pneumonia, and idiopathic interstitial pneumonia, including cryptogenic promoters' pneumonia and fibrosis (sclerosing) mediastinitis, which are frequently detected in patients with IgG4-RD. A systematic review of the clinical records of the Mayo Clinic, Rochester, MN revealed 127 cases meeting the current diagnostic criteria for $\lg G 4-R D$, and 16 (12.6\%) with lung or thoracic involvement (12).

Patients with lgG4-RD have been reported to be at risk of malignancy, suggesting that $\lg G 4-R D$ is a paraneoplastic syndrome, especially one year after onset. Yamada et al. (13) analyzed 334 patients, in which 67 malignancies were noted in 57 patients, the most frequent of which was lung cancer, in 12 patients. In addition, an analysis of 294 patients with non-small cell lung cancer who underwent a surgical resection found $20 \lg G 4$ + plasma cells per high-power field in 35 patients, of whom six were $\lg G 4 / \lg G>40 \%$ (14). These reports suggest a strong association between $\lg G 4-R D$ and lung cancer, demonstrating the importance of the strict exclusion of lung cancer in the diagnosis of $\lg G 4-R D$, and the monitoring of these patients for the development of malignancies.

There are studies suggesting that cancer cells and lgG4positive plasma cells coexist with the obliterative phlebitis in the same nodule, rather than presenting as an individval complication. The production of lgG4 plasma cells is thought to be a response to unknown antigens. Further research is needed to investigate the pathogenesis of lgG4-RD.

In conclusion, lgG4-related disease contains neoplastic, autoimmune and infectious processes. The clinical, radiological histopathological findings and serum lgG4 level should be evaluated together. The lungs should be kept in mind in the differential diagnosis is a newly defined entity. If possible, a complete resection will be necessary, both for definite treatment and for recurrence.

\section{CONFLICTS OF INTEREST}

None declared.

\section{AUTHOR CONTRIBUTIONS}

Concept - O.D., N.O.B., S.C., C.A., I.Y.; Planning and Design O.D., N.O.B., S.C., C.A., I.Y.; Supervision - O.D., N.O.B., S.C., C.A., I.Y.; Funding - O.D., N.O.B., S.C., C.A., I.Y.; Materials - O.D.; Data Collection and/or Pro- 
cessing - I.Y., N.O.B.; Analysis and/or Interpretation C.A.; Literature Review - O.D.; Writing - O.D.; Critical Review - O.D.

\section{YAZAR KATKILARI}

Fikir - O.D., N.O.B., S.C., C.A., I.Y.; Tasarım ve Dizayn O.D., N.O.B., S.C., C.A., I.Y.; Denetleme - O.D., N.O.B., S.C., C.A., I.Y.; Kaynaklar - O.D., N.O.B., S.C., C.A., I.Y.; Malzemeler - O.D.; Veri Toplama ve/veya İşleme - I.Y., N.O.B.; Analiz ve/veya Yorum - C.A.; Literatür Taraması - O.D.; Yazıyı Yazan O.D.; Eleştirel İnceleme - O.D.

\section{REFERENCES}

1. Stone JH, Zen Y, Deshpande V. IgG4-related disease. N Engl J Med 2012; 366:539-51. [CrossRef]

2. Zen $Y$, Nakanuma $Y$. IgG4-related disease: a crosssectional study of 114 cases. Am J Surg Pathol 2010; 34:1812-9. [CrossRef]

3. Rose AG, McCormick S, Cooper K, Titus JL. Inflammatory pseudotumor (plasma cell granuloma) of the heart. Report of two cases and literature review. Arch Pathol Lab Med 1996; 120:549-54.

4. Cerfolio RJ, Allen MS, Nascimento AG, Deschamps C, Trastek VF, Miller DL, et al. Inflammatory pseudotumors of the lung. Ann Thorac Surg 1999; 67:933-6. [CrossRef]

5. Wallace ZS, Mattoo H, Carruthers M, Mahajan VS, Della Torre $E$, Lee $H$, et al. Plasmablasts as a biomarker for lgG4-related disease, independent of serum $\operatorname{lgC} 4$ concentrations. Ann Rheum Dis 2015; 74:190-5. [CrossRef]

6. Dahabreh J, Zisis C, Arnogiannaki N, Katis K. Inflammatory pseudotumor: a controversial entity. Eur J Cardiothorac Surg 1999; 16:670-3. [CrossRef]
7. Kamisawa T, Zen Y, Pillai S, Stone JH. IgG4-related disease. Lancet 2015; 385:1460-71. [CrossRef]

8. Deshpande V, Zen Y, Chan JK, Yi EE, Sato Y, Yoshino T, et al. Consensus statement on the pathology of $\lg G 4$ related disease. Mod Pathol 2012; 25:1181-92. [CrossRef]

9. Ryu JH, Sekiguchi H, Yi ES. Pulmonary manifestations of immunoglobulin G4-related sclerosing disease. Eur Respir J 2012; 39:180-6. [CrossRef]

10. Choi IH, Jang SH, Lee S, Han J, Kim TS, Chung MP. A case report of $\lg G 4$-related disease clinically mimicking pleural mesothelioma. Tuberc Respir Dis (Seoul) 2014; 76:42-5. [CrossRef]

11. Shrestha B, Sekiguchi H, Colby TV, Graziano P, Aubry MC, Smyrk TC, et al. Distinctive pulmonary histopathology with increased $\lg G 4$-positive plasma cells in patients with autoimmune pancreatitis: report of 6 and 12 cases with similar histopathology. Am J Surg Pathol. 2009; 33: 1450-62. [CrossRef]

12. Zhu L, Li J, Liu C, Ding W, Lin F, Guo C, Liu L. Pulmonary inflammatory myofibroblastic tumor versus $\lg G 4$ related inflammatory pseudotumor: differential diagnosis based on a case series. J Thorac Dis 2017; 9:598-609. [CrossRef]

13. Yamada K, Yamamoto M, Saeki T, Mizushima I, Matsui $S$, Fujisawa $Y$, et al. New clues to the nature of immunoglobulin G4-related disease: a retrospective Japanese multicenter study of baseline clinical features of 334 cases. Arthritis Res Ther 2017; 19:262. [CrossRef]

14. Fujimoto M, Yoshizawa A, Sumiyoshi S, Sonobe M, Kobayashi $M$, Koyanagi I, et al. Stromal plasma cells expressing immunoglobulin G4 subclass in non-small cell lung cancer. Hum Pathol 2013; 44: 1569-76. [CrossRef] 